\title{
CYP2E1 TESTIS EXPRESSION AND ALCOHOL- MEDIATED CHANGES OF RAT SPERMATOGENESIS INDICES AND TYPE I COLLAGEN
}

\author{
Ganna M. SHAYAKHMETOVA ${ }^{1}$, Larysa B. BONDARENKO ${ }^{1}$, Valentina M. KOVALENKO ${ }^{1}$, and \\ Volodymyr V. RUSCHAK ${ }^{2}$
}

\begin{abstract}
SI "Institute of Pharmacology \& Toxicology” National Academy of Medical Sciences of Ukrainel, SI "Institute of Molecular Biology \& Genetics” National Academy of Sciences of Ukraine², Kyiv, Ukraine
\end{abstract}

\author{
Received in October 2012 \\ CrossCheck in February 2013 \\ Accepted in February 2013
}

\begin{abstract}
This study is a complex investigation of alcohol-mediated changes in CYP2E1 mRNA and protein expression in the testes, as well as spermatogenesis indices and type I collagen amino acid contents, in male rats. Wistar albino male rats were divided into two groups: I - control (intact animals), II - experimental (chronic alcoholism, exposure to a $15 \%$ ethanol aqueous solution during 150 days). The destructive changes in the spermatogenic epithelium were accompanied by a decrease in sperm number and motility time. CYP2E1 mRNA and protein expression were elevated in the testes 3 and 1.4 times, respectively. Also, significantly lower contents of lysine, glutamic acid, serine, proline, alanine, valine, and phenylalanine residues accompanied by an increase of hydroxyproline, glycine, and threonine residue contents were detected in the skin type I collagen of the experimental group. Chronic ethanol consumption caused testicular failure along with an overexpression of CYP2E1 mRNA and protein in the testes as well as quantitative changes in type I collagen amino acid contents. The profound alcohol-mediated changes in collagen type I amino acid contents may have affected the spermatogenic epithelium state. The modulation of testicular cytochrome P450 2E1 mRNA and protein expression could change the functioning of this isozyme in target organs and take part in the mechanism of ethanol gonadotoxicity.
\end{abstract}

KEY WORDS: chronic alcoholism, ethanol, gonadotoxicity, motility

Alcohol abuse has a negative effect on all three factors that influence the male reproductive function: hypothalamus-hypophysis-gonads system, endocrine glands, and hormones (1). It is well-known that chronic alcohol dependence causes testicular abnormalities and sexual dysfunctions both in humans and animals $(2,3)$; however, the exact mechanisms of ethanol-induced damage to the male reproductive organs remain unclear. A great number of epidemiological studies have demonstrated that alcohol abuse is associated with low testosterone production and testicular atrophy (4). Ethanol-induced oxidative stress results from the combined impairment of antioxidant defences as well as from the production of reactive oxygen species by the mitochondrial electron transport chain, the alcohol-inducible cytochrome P450 (CYP)2E1, and activated phagocytes. Furthermore, during the metabolism of ethanol, CYP2E1 also generates hydroxyl ethyl free radicals (HER). The mechanisms by which oxidative stress contributes to alcohol gonadotoxicity are still not fully clear (5).

It has also been shown that the negative effects of alcohol on the testes could set in through the initiation 
of oxidative damage as a result of the increased generation of free radicals and the exhaustion of the antioxidant pool (6). Taking into account that testicular membranes are rich in fatty acids, which are sensitive to oxidative damage, it could be suggested that lipid peroxidation is also a factor in the development of gonad dysfunction (7). Alcohol-induced changes in the testes are often connected with severe cell damage, which causes their necrosis or apoptosis $(1,8)$.

Some investigations have demonstrated that acetaldehyde possesses greater toxicity than ethanol during testosterone production, therefore directly inhibiting protein kinase $\mathrm{C}-\mathrm{a}$ key enzyme in testosterone biosynthesis (9). It can also cause changes in the pro- and antioxidants balances of testis cells (10). Ethanol conversion to acetaldehyde and free radicals may take place directly at the testes. CYP2E1, P450 reductase, and other enzymes with lipoxygenase/ peroxidase-like behaviour could also be involved (11).

Ethanol induces changes in the protein metabolism of probably every organ or tissue system; e.g., increased hepatic collagen resulting from cirrhosis, myosin reduction resulting from cardiomyopathy, or the loss of skeletal collagen resulting from osteoporosis (12). Oxidative mechanisms can contribute to changes in collagen biosynthesis by triggering the release of pro-fibrotic cytokines and collagen gene expression in target cells (5).

Chronic alcoholism $\left(6 \mathrm{~g} \mathrm{~kg}^{-1}\right.$ per day x 60 days $)$ has been associated with fatty liver and collagen accumulation (13). Collagens VI and XIV, procollagenIII-N-propeptide, and hyaluronic acid appear to be sensitive markers of fibrotic transformation in alcoholics. The correlation between procollagen-IIIN-propeptide and TGF-betal emphasizes their role in hepatic fibrogenesis (14). Collagen obtained from ethanol-fed rats showed alterations in solubility properties, increased fluorescence, peroxidation, and aldehyde content (13). Certain quantitative changes in the collagen contents and qualitative changes of its structure have been demonstrated (15).

Considering that quantitative changes in collagen structure correlate with male reproductive system parameters such as percentage of normal sperm and sensitivity to testicular degeneration (16), an analysis of the effects that alcoholism has on collagen and the reproductive system is of great importance.

The aim of this study was to investigate the alcohol-mediated changes of testes CYP2E1 mRNA and protein expression, spermatogenesis indices, and type I collagen amino acid contents in male rats.

\section{MATERIALS AND METHODS}

Wistar albino male rats, body weight (b.w.) of $150 \mathrm{~g}$ to $170 \mathrm{~g}$, were used in the study. They were kept under a controlled temperature (from $22{ }^{\circ} \mathrm{C}$ to $24{ }^{\circ} \mathrm{C}$ ), relative humidity of $40 \%$ to $70 \%$, lighting ( $12 \mathrm{~h}$ light-dark cycle), and on a standard pellet feed diet ("Phoenix" Ltd., Ukraine). The study was performed in accordance with the recommendations of the European Convention for the Protection of Vertebrate Animals used for Experimental and other Scientific Purposes and approved by the Institutional Animal Care and Use Committee.

For the experimental (chronic alcoholism) model, reproducing male rats were selected according to the method for measuring voluntary alcohol selfadministration in rats, which provides a continuous choice between an alcohol solution and water (twobottle preference test) (17). The six selected rats were used for chronic alcoholism modelling by replacing water with a $15 \%$ ethanol solution during 150 days (18). Six intact male rats (of the same age and weight) were used as controls. From the beginning of the experiment, they were kept in the same conditions as experimental animals but were given only water $a d$ libitum.

After 150 days, both the experimental and control rats were sacrificed under a mild ether anaesthesia by decapitation. The skin, testes and epididymis were used for investigation.

Epididymal sperm quality was evaluated according to generally accepted methods (19). The right testicle was used for the evaluation of morphologic and morphometric parameters and spermatogenesis. It was fixed in a $10 \%$ solution of neutral formalin, dehydrated in ethanol solutions, and embedded in paraffin. Histologic sections $(6 \mathrm{~mm})$ were stained by haematoxylin and eosin. The histological examination was performed under a light microscope $(100 \mathrm{x})$. The determination of the spermatogenic index was carried out according to a four-point system (19). Simultaneously, the qualitative changes to the spermatogenic epithelium were evaluated: cells desquamation (shedding of epithelial elements), epithelium exfoliation (detachment) from the tubule basal membrane, and the presence of cell-free regions ("windows"). 
Skin and bone type I collagen was extracted and purified according to Bondarenko et al. (20). All of the procedures were carried out in cold regime $\left(+4{ }^{\circ} \mathrm{C}\right)$. The fractionation of pure type I collagen was carried out with $\mathrm{NaCl}$ according to Trelstad et al. and Rubin et al. $(21,22)$. Collagen preparations purity was controlled electrophoretically (23). Collagen fractions were hydrolysed for $24 \mathrm{~h}$ with $6 \mathrm{~mol} \mathrm{~L}^{-1} \mathrm{HCl}$ at $105{ }^{\circ} \mathrm{C}$ (24). Their amino acid compositions were analysed by ion exchange chromatography with the AAA- 881 amino acid analyser (Czech Republic).

The expression of CYP2E1 mRNA in the testes was determined by a reversed transcriptase polymerase chain reaction (RT-PCR). Testes samples $(50 \mathrm{mg}$ ) were collected, quickly frozen in liquid nitrogen, and stored at $-80^{\circ} \mathrm{C}$ before RNA extraction. The isolation of total mRNA was carried out with a TRI-Reagent (Sigma, USA). The integrity and concentration of RNA was analysed in a $2 \%$ agarose gel. First-strand complementary DNA was synthesized using a FirstStrand cDNA Synthesis Kit (Fermentas, Germany). The reaction mixture contents for PCR, amplification protocol, and specific primers for the CYP2E1 gene were chosen according to S.M. Lankford et al. (25). The primer sequences were: sense, 5'CTTCGGGCCAGTGTTCAC-3' and anti-sense, 5'CCCATATCTCAGAGTTGTGC-3'. RT-PCR with primers of $\beta$-actin (sense, ${ }^{\prime}$ GCTCGTCGTCGACAACGGCTC - 3' and antisense 5' - CAAACATGAT CTGGGTCATCTTCT 3') was carried out for internal control. All of the primers were synthesized by "Metabion" (Germany). The MyCycler termocycler (BioRaD, USA) was used for amplification. PCR products (CYP2E1-744 bp and $\beta$-actin-353 bp) were separated in a $2 \%$ agarose gel, stained with ethidium bromide, and visualized under a UV transilluminator (BIORAD, USA). Data analysis was carried out with Quantity One Software (USA) and presented in relative units as the ratio of CYP2E1 mRNA contents and $\beta$-actin mRNA contents.

CYP2E1 protein concentration was determined by Western Blot analysis, using specific polyclonal antibodies for mouse CYP2E1 protein, produced in the Institute of Molecular Biology \& Genetics of the National Academy of Sciences of Ukraine. Glyceraldehyde-3-phosphate dehydrogenase (GAPDH) was used as an internal loading control with polyclonal antibodies (Sigma, USA). The protein concentration in the cell lysate was quantified by the Bradford method (26). Equal amounts of protein per sample $(50 \mu \mathrm{g})$ were used. The electrophoretic fractionation of proteins was carried out in $12 \%$ PAAG (with $0.1 \%$ SDS) according to the Laemmli method (27). The proteins were transferred to the nitrocellulose membrane. After blocking in a TBST buffer, which contained $5 \%$ defatted dry milk, the membrane was incubated with CYP2E1 antibodies $(1 / 400, v / w)$, and then with anti-rabbit IgG secondary antibodies (Sigma, 1/500, v/w). The CYP2E1 protein was visualized by chemiluminescence. Blots were photographed and densitometric analysis performed using the ImageJ software. CYP2E1 protein data was presented in relative units as the ratio of CYP2E1 protein contents and control GAPD protein contents in the same gel band.

The obtained data were calculated by one-way analysis of variance (ANOVA) and expressed as the mean \pm standard error of the mean ( $\mathrm{M} \pm$ S.E.M.). Data were compared using Tukey's test. Differences were considered to be statistically significant at $p<0.05$ (28).

\section{RESULTS}

Cauda epididymal sperm quantitative and qualitative parameters significantly deteriorated after 150 days of $15 \%$ ethanol treatment (Table 1). The sperm count and motility time decreased in comparison with the control group by $36 \%$ and $14 \%$, respectively. Simultaneously, a tendency toward a lower sperm osmotic resistance was also registered.

Almost regardless of the cellular target within the reproductive system, the most common morphological negative consequence was a disturbance in spermatogenesis. In our experiment, the impairment of sperm quality in alcohol-dependent rats was accompanied by a development of destructive changes in their spermatogenic epithelium. According to the data from Table 2, the spermatogenic index in the experimental group decreased in comparison with controls (along with mitotic activity and spermatogonia number). At the same time, the number of cells during the $12^{\text {th }}$ stage of meiosis, characterized by the meiotic division of primary spermatocytes, demonstrated only a tendency toward decreasing.

Apart from the abovementioned quantitative changes, qualitative changes in the spermatogenic epithelium were also present in the seminiferous tubules. Increased (4.1 times) epithelial cell desquamation levels were observed in the experimental 
group (Table 2). Extreme degenerative changes in the testes, such as epithelium exfoliation from the tubule basal membrane and the presence of cell-free regions ("windows"), were also present in a large quantity of experimental animals (Figure 1, Table 2).
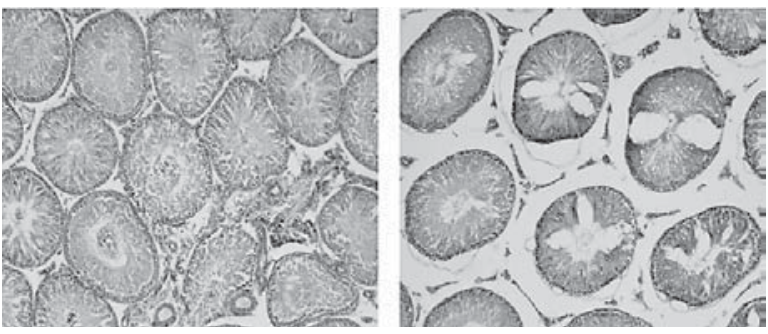

Figure 1 Degenerative changes in the testes of experimental rats after 150 days of $15 \%$ ethanol consumption: $A$ - desquamation of epithelial cells, B - tubules with loss of spermatogenic epithelium ("windows"). Hematoxilin and eosine, x100.

To evaluate the effect of ethanol exposure on the transcriptional activation of CYP2E1 in the testes, an RT-PCR was performed. As the ethanol-mediated induction of CYP2E1 is known to occur through protein stabilization (29), we used Western Blot analyses to assess the protein levels. We found that the amount of the CYP2E1 protein in the testes of alcohol-treated rats increased 1.4 times (Figure 2). The increase in CYP2E1 protein was accompanied by a corresponding increase of CYP2E1 mRNA content, as determined by the RT-PCR (Figure 3).

According to the data from Figure 2, chronic alcoholisation caused a three-fold increase in CYP2E1 mRNA expression in rat testes in comparison with controls.

We also analysed the effect of chronic alcoholism on collagen amino acid content. The changes in rat skin type I collagen amino acid content induced by continuous alcohol consumption are shown in Table 3. Statistically significant changes were registered for 10 amino acids.

Skin type I collagen of alcoholic rats contains significantly lower contents of lysine $(-12.4 \%)$, glutamic acid (-9.04\%), serine (-11.9\%), proline
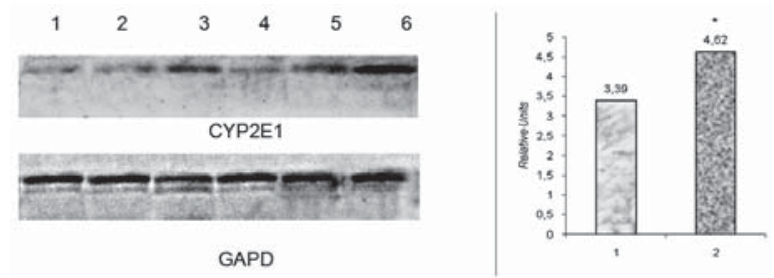

A

Figure 2 CYP2E1 protein content in the testes after 150 days of $15 \%$ ethanol consumption:

A - Western Blot analysis of CYP2E1 content with specific polyclonal antibodies raised against recombinant CYP2E1: 1 to 3 - control; 4 to $6-$ experimental. Each band represents protein content in the testes of different animals;

$B$-Average content of CYP2E1 protein in testes lysate: 1 - control, 2 - experimental. ${ }^{*} \mathrm{p}<0.05$ in comparison with control
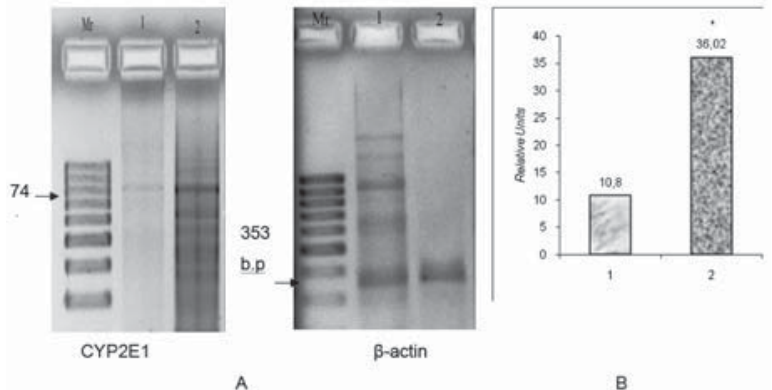

Figure 3 CYP2E1 $\mathrm{mRNA}$ in the testes after 150 days of $15 \%$ ethanol consumption:

$A$ - electrophoregram of CYP2E1 (744 bp) and reference-gene $\beta$-actin (353 bp) RT-PCR products (arrows indicate appropriate DNA fragments): 1 control, 2 - chronic alcoholism.

$B$ - Average rate of CYP2E1 $m R N A$ expression in the testes: 1 - control, 2 - experimental. $*_{\mathrm{p}}^{\mathrm{p}}<0.05$ in comparison with control

$(-3.7 \%)$, alanine $(-9.8 \%)$, valine $(-22.3 \%)$, phenylalanine $(-16.7 \%)$ residues, accompanied by higher contents of hydroxyproline ( $+25.1 \%)$, glycine $(+2.7 \%)$, and threonine $(+10.1 \%)$ residues. It is clear that chronic alcohol consumption caused certain quantitative changes in collagen molecules, as previously demonstrated for other pathologies associated with CYP2E1 induction $(16,20)$.

Table 1 Rat sperm parameters after 150 days of $15 \%$ ethanol consumption (M \pm S.E.M., $\mathrm{n}=6)$

\begin{tabular}{lcc}
\hline \multirow{2}{*}{ Indices } & \multicolumn{2}{c}{ Animal groups } \\
\cline { 2 - 3 } & Control & Experimental \\
\hline Sperm number $/ \mathrm{x} 10^{6} \mathrm{~mL}^{-1}$ & $82.17 \pm 7.07$ & $44.40 \pm 4.64^{*}$ \\
\hline Sperm motility time $/ \mathrm{min}$ & $423.16 \pm 17.70$ & $363.50 \pm 16.00^{*}$ \\
\hline Sperm osmotic resistance $/ \% \mathrm{KCl}$ & $2.83 \pm 0.22$ & $2.40 \pm 0,21$ \\
\hline
\end{tabular}

${ }^{*} \mathrm{p}<0.05$ in comparison with control 


\section{DISCUSSION}

In our experiment, chronic ethanol selfadministration in male rats caused the development of testicular failure manifested by the deterioration of the quantitative and qualitative parameters of cauda epididymal sperm and destructive changes in the spermatogenic epithelium. These results are in accord with data from other authors, who have demonstrated that chronic alcohol intoxication is accompanied by testicular injury $(2,3)$. Ethanol oxidation is a necessary stage for its toxic realization. Quintans et al. (11) proved that the metabolic transformation of ethanol to acetaldehyde and free radicals could take place directly in the testes.
The molecular regulation of CYP2E1 induction is realized through transcriptional, post-transcriptional, and post-translational mechanisms and depends on the dose, duration, manner of administration, and specific structure of the inducing agent (30). CYP2E1 induction by ethanol has been suggested to include two stages: a post-transcriptional mechanism for low doses and a transcriptional mechanism for high doses (31). Our results may have proven that chronically administered ethanol induces CYP2E1 expression not only in the liver [as was previously described in a number of reviews $(35,37-39)]$, but also in the testes, possibly through each of the abovementioned mechanisms. The increase in CYP2E1 mRNA content from our experiment suggests a transcriptional

Table 2 Spermatogenic epithelium indices in control and experimental rats after 150 days of $15 \%$ ethanol consumption $(M \pm$ S.E.M., $\mathrm{n}=6)$

\begin{tabular}{lcc}
\hline Indices & \multicolumn{2}{c}{ Animal groups } \\
\cline { 2 - 3 } & Control & Experimental \\
\hline $\begin{array}{l}\text { Spermatogenic index (stages of spermatogenesis total / } \\
\text { number of examined tubules) }\end{array}$ & $3.623 \pm 0.012$ & $3.523 \pm 0.027^{*}$ \\
\hline Spermatogonia / number per tubular cross section & $67.605 \pm 0.890$ & $57.845 \pm 1.864^{*}$ \\
\hline $12^{\text {th }}$ stage of meiosis / \% & $2.667 \pm 0.715$ & $2.000 \pm 0.258$ \\
\hline Desquamated epithelium / \% & $1.167 \pm 0.447$ & $4.833 \pm 1.537$ \\
\hline Exfoliation of epithelium / \% & 0 & $0.833 \pm 0.307^{*}$ \\
\hline "Windows" / \% & $0.500 \pm 0.342$ & $3.333 \pm 1.085$ \\
\hline
\end{tabular}

${ }^{*} \mathrm{p}<0.05$ in comparison with control

Table 3 Rat skin type I collagen amino acid contents (residues/1000 residues) in control and experimental animals after 150 days of $15 \%$ ethanol consumption ( $M \pm S . E . M ., \mathrm{n}=6)$.

\begin{tabular}{lcc}
\hline \multirow{2}{*}{ Amino acid } & \multicolumn{2}{c}{ Animal groups } \\
\cline { 2 - 3 } Hydroxylysine & Control & Experimental \\
\hline Lysine & $4.30 \pm 0.28$ & $4.60 \pm 0.90$ \\
\hline Histidine & $29.80 \pm 0.70$ & $26.10 \pm 0.62^{*}$ \\
\hline Arginine & $4.69 \pm 0.40$ & $4.70 \pm 0.20$ \\
\hline Hydroxyproline & $49.80 \pm 3.60$ & $48.80 \pm 1.24$ \\
\hline Aspartic acid & $90.90 \pm 1.30$ & $113.0 \pm 2.60^{*}$ \\
\hline Threonine & $46.70 \pm 4.10$ & $48.90 \pm 3.96$ \\
\hline Serine & $17.80 \pm 0.20$ & $19.60 \pm 0.40^{*}$ \\
\hline Glutamic acid & $38.80 \pm 0.20$ & $34.20 \pm 0.20^{*}$ \\
\hline Proline & $75.20 \pm 0.50$ & $68.40 \pm 2.40^{*}$ \\
\hline Glycine & $127.10 \pm 0.70$ & $122.40 \pm 0.80^{*}$ \\
\hline Alanine & $323.70 \pm 2.70$ & $332.56 \pm 1.22^{*}$ \\
\hline Valine & $104.40 \pm 3.10$ & $94.20 \pm 1.36^{*}$ \\
\hline Methionine & $27.10 \pm 0.60$ & $21.05 \pm 0.95^{*}$ \\
\hline Isoleucine & $6.20 \pm 0.10$ & $6.80 \pm 1.90$ \\
\hline Leucine & $10.80 \pm 0.80$ & $11.80 \pm 1.87$ \\
\hline Tyrosine & $29.20 \pm 1.70$ & $29.10 \pm 5.25$ \\
\hline Phenylalanine & $3.70 \pm 0.20$ & $3.80 \pm 0.32$ \\
\hline
\end{tabular}

${ }^{*} \mathrm{p}<0.05$ in comparison with control 
regulation of its expression, or mRNA stabilization. However, taking into account the considerable increase of CYP2E1 protein content, its stabilization by ethanol and the prolongation of its half-life time could also be presumed $(30,33,34)$.

The CYP2E1 expression increase in the testes of alcoholic rats could have had a pronounced importance as a mechanism that contributes to the development of testosterone-dependent testicular malfunction. At the present, data regarding the mechanism of alcoholmediated testosterone biosynthesis inhibition in the testes are both controversial and contradictory (1). Considering that the chronic consumption of ethanol led to a significant induction of the testicular CYP2E1 isoform, the stimulation of free radicals could be a subsequent negative stage $(30,34)$. Other authors have confirmed this conclusion by demonstrating changes in pro- and antioxidant balances in rat testes after repeated administrations of ethanol (35). Lipid peroxidation is a key factor in damaging cell membranes, which means that cytotoxic action could be realized not only by oxygen reactive forms but also by the terminal products of the peroxide catabolism. Testis CYP2E1 is localized in the Leydig cells, where testosterone biosynthesis takes place $(36,37)$. Consequently, these structures and the damage of their microenvironment by free radicals resulting from ethanol biotransformation could be a reason for the decrease in steroidogenesis enzyme activity. The cell membrane damage caused by enhanced lipid peroxidation is one of the causes for the decrease in the membrane-related enzymatic activity involved in steroid biosynthesis. In our opinion, the activation of CYP2E1-dependent ethanol-metabolizing systems in steroidogenic cells could determine at least part of the negative effects on the testes caused by alcohol. Furthermore, the CYP2E1-dependent generation of reactive oxygen species could play a role in the inhibition of sperm motility and loss of fertility (38).

In our experiment, changes mediated by chronic alcohol consumption could have also partially resulted from the degenerative processes in the reproductive organs caused by disturbances in the protein, lipid, and nucleic acid metabolisms of the rats. As a result, acetaldehyde was able to produce adducts upon reaction with amino groups, nucleic acid bases, or phosphatidylethanolamine and others (39-41).

An important aspect of spermatogenesis is the detachment of germ cells from the basement membrane and their subsequent migration towards the tubule lumen. Procollagen I, a precursor of type I collagen, is a trimer consisting of two $\alpha 1$ chains and one $\alpha 2$ chain whose sequences are encoded by two different genes; COL1A1 and COL1A2, respectively (42). The distribution of procollagen I within the seminiferous tubules of immature and adult mice correlates with the process of germ cell attachment and detachment from the basement membrane. The unique distribution pattern of procollagen I in adult mouse testes implies a possible role for COL1A1, COL1A2, and procollagen $\mathrm{I}$ in regulating the adhesion of spermatogonia and preleptotene spermatocytes to the basement membrane and the detachment and migration of spermatocytes and spermatids towards the lumen during spermatogenesis (43).

The alcohol-mediated changes in collagen amino acid composition reported here may induce disturbances in physicochemical qualities. Lysine residues, along with hydroxylisine and histidine (44), participate in collagen cross-linking. Changes in the ratio of hydroxylysine : lysine : histidine residues could seriously influence the number and type of cross-links in the collagen fibrils. This might induce changes in the mechanical strength and elasticity/rigidity of the extracellular matrix. Our results regarding changes in lysine, proline, and hydroxyproline residues are in accordance with data from other authors (45-47).

Changes in the number of glutamic acid, threonine, serine, and threonine residues could cause changes in the surface charge of collagen molecules $(49,53)$, whereas changes in the quantity of valine, alanine, and phenylalanine residues could influence the level of collagen helix rigidity (49). In addition, changes in glycine residues could affect the number of Arg-GlyAsp domains responsible for the processes of cell adhesion to collagen structures (50-52). Glycine residues in collagen molecules are also part of the special loci responsible for interactions with chaperones as well as for procollagen to collagen processing (53).

Our study indicates the presence of qualitative changes in the skin type I collagen of rats exposed to chronic alcohol consumption. These changes could lead to alterations in the helix structure, surface charge, rigidity, number, types of cross-links and specific loci responsible for cell adhesion, interaction with chaperons, and the processing of procollagen to collagen.

We could hypothesize that these changes are caused by the impact of ethanol and the products of its metabolism on collagen synthesis (54). The pathological changes in the amino acid metabolism 
could also influence the collagen metabolism (55). The ability of most amino acids to regulate protein biosynthesis by the stimulation of $70 \mathrm{kD}$-ribosomal proteinS6-kinase has been established in vitro (56).

On the other hand, taking into account the existence of collagen gene polymorphisms $(57,58)$, the changes could have also been the result of disturbances in the transcription rates of different genes from the same collagen type I superfamily, as it was previously demonstrated for osteogenesis imperfecta (59). Such changes to collagen molecules could thus affect the properties and correct functioning of the spermatogenic epithelium and other reproductive organ tissues.

It could also be hypothesized that the changes in collagen structure mediated by chronic ethanol consumption were partially caused by oxygen reactive forms produced by cytochrome P450 2E1 (30,34). As it was previously mentioned, these reactive oxygen species were reported to mediate the paracrine stimulation of type I collagen synthesis in different stages of this process (60) and caused genotoxic effects on rodent germ cells (61).

\section{CONCLUSION}

The results obtained in this investigation demonstrate that chronic ethanol administration in male rats caused testicular failure accompanied by an overexpression of CYP2E1 mRNA and protein in the testes, as well as quantitative changes in type I collagen amino acid contents. It could be suggested that profound alcohol-mediated changes in collagen type I amino acid contents unfavourably affected the spermatogenic epithelium state. The modulation of testicular cytochrome P450 2E1 mRNA and protein expression could change the functioning of this isozyme in target organs and thus take part in the mechanism of ethanol gonadotoxicity. Our data add to the understanding of the pathogenetic mechanisms of male infertility associated with the overconsumption of alcohol.

\section{REFERENCES}

1. Emanuele MA, Emanuele N. Alcohol and the male reproductive system. Alcohol Res Health 2001;25:283-7.

2. Muthusami KR, Chinnaswamy P. Effect of chronic alcoholism on male fertility hormones and semen quality. Fertil Steril 2005;84:919-24. doi: 10.1016/j.fertnstert.2005.04.025
3. El-Sokkary GH. Quantitative study on the effects of chronic ethanol administration on the testis of adult male rat. Neuro Endocrinol Lett 2001;22:93-9.

4. Karagiannis A, Harsoulis F. Gonadal dysfunction in systemic diseases. Eur J Endocrinol 2005;152:501-13. doi: 10.1530/ eje. 1.01886

5. Albano E. Alcohol, oxidative stress and free radical damage. Proc Nutr Soc 2006;65:278-90.

6. Turner T, Lysiak JJ. Oxidative stress: A common factor in testicular dysfunction. J Androl 2008;29:488-98. doi: 10.2164/jandrol.108.005132

7. Dosumu OO, Akinola OB, Vakang EN. Alcohol-induced testicular oxidative stress and cholesterol homeostasis in rats - The therapeutic potential of virgin coconut oil. Middle East Fertil Soc J 2012;17:122-8. doi:10.1016/j. mefs.2011.12.005

8. Mathur PP, Huang L, Kashou A, Vaithinathan S, Agarwal A. Environmental toxicants and testicular apoptosis. Open Reprod Sci J 2011;3:114-24.

9. Wanderlay MI, Udrisar DP. Inhibitory action of in vitro ethanol and acetaldehyde exposure on LHRH-and phorbol ester-stimulated testosterone secretion by rat testicular interstitial cells. Acta Physiol Pharmacol Ther Latinoam 1994;44:135-41.

10. Aitken RJ, Roman SD. Antioxidant systems and oxidative stress in the testes. Oxid Med Cell Longev 2008;1:15-24.

11. Quintans LN, Castro GD, Castro JA. Oxidation of ethanol to acetaldehyde and free radicals by rat testicular microsomes. Arch Toxicol 2005;79:25-30. doi: 10.1007/s00204-004-06095

12. Preedy VR, Adachi J, Koll M, Mantle D, Patel VB, Peters TJ. Protein metabolism in alcohol misuse and toxicity. In: Watson RR, Preedy VR, editors. Nutrition and alcohol. London: CRC Press; 2003. p. 261-98.

13. Kaviarasan $S$, Viswanathan $P$, Ravichhandran MK, Anuradha CV. (-) Epigallocatechin gallate (EGCG) prevents lipid changes and collagen abnormalities in chronic ethanol-fed rats. Toxicol Mech Methods 2008;18:425-32. doi: 10.1080/ 15376510701511737

14. Strikel F, Urbaschek R, Schuppan D, Poeschl G, Oesterling C, Conradt C, McCuskey RS, Simanowski UA, Seitz HK. Serum collagen type VI and XIV and hyaluronic acid as early indicators for altered connective tissue turnover in alcoholic liver disease. Dig Dis Sci 2001;46:2025-32.

15. Kaviarasan S, Viswanathan P, Ravichhandran MK. Fenugreek seed (Trigonella foenum graceum) polyphenols inhibit ethanol-induced collagen and lipid accumulation in rat liver. Cell Biol Toxicol 2007;23:373-83. doi: 10.1007/s10565-0079000-7

16. Bondarenko LB, Shayakhmetova GM, Matvienko AV, Kovalenko VM. Diabetes-mediated changes in rat type I collagen and spermatogenesis indices. Rom J Diabetes Nutr Metab Dis 2012;19:245-54. doi: 10.2478/v10255-012-00304

17. Richter CP, Campbell KH. Alcohol taste thresholds and concentrations of solution preferred by rats. Science 1940;91:507-8. doi: 10.1126/science.91.2369.507

18. Burov YV, Vedernikova NN. [Neurochemistry and Pharmacology of Alcoholism, in Russian]. Moscow: Medicina; 1985.

19. Boekelheide K, Chapin R. Male reproductive toxicology. In: Costa LG, Hodgson E, Lawrence DA, Ozolins TR, Reed DJ, 
Greenlee WF, editors: Current protocols in toxicology. Chapter 16. New York (NY): John Wiley \& Sons, Inc; 2005 .

20. Bondarenko LB, Shayakhmetova GM, Byshovets TF, Kovalenko VM. Pyrazinamide-mediated changes in rat type I collagen and spermatogenesis indices. Acta Poloniae Pharmaceut Drug Res 2011;68:285-90.

21. Trelstad RL, Catanese VM, Rubin DF. Collagen fractionation: separation of native types I, II and III by differential precipitation. Anal Biochem 1976;71:114-8. doi 10.1016/0003-2697(76)90016-6

22. Rubin AL, Drake MP, Davison PF, Pfahl D, Speakman PT, Schmitt FO. Effect of pepsin treatment on the interaction properties of tropocollagen macromolecules. Biochemistry 1965;4:181-90. doi: 10.1021/bi00878a001

23. Maurer G. [The Disk-Electrophoresis, in Russian]. Moscow: Mir; 1971.

24. Deveni T, Gherghey J. [The Aminoacids, Peptides and Proteins, in Russian]. Moscow: Mir; 1976.

25. Lankford SM, Bai SA, Goldstein JA. Cloning of canine cytochrome P-450 2E1 cDNA: identification and characterization of two variant alleles. Drug Metab Dispos 2000;28:981-6.

26. Bradford MM. Rapid and sensitive method for the quantitation of microgram quantities of protein utilizing the principle of protein-dye binding. Anal Biochem 1976:72:248-54. doi: 10.1016/0003-2697(76) 90527-3

27. Laemmli UK. Cleavage of structural proteins during the assembly of the head of bacteriophage T4. Nature 1970;227:680-5. doi:10.1038/227680a0

28. Glantz S.A. Primer of Biostatistics. New York: The McGraw-Hill Companies, Inc.; 2005.

29. Cederbaum AI. CYP2E1-biochemical and toxicological aspects and role in alcohol-induced liver injury. Mt Sinai J Med 2006;73:657-72.

30. Lieber CS. Cytochrome P4502E1: Its physiological and pathological role. Physiol Rev 1997;77:517-44.

31. Ronis MJJ, Huang J, Crouch C, Mercado C, Irby D, Valentine CR, Lumpkin CK, Ingelman-Sundberg M, Badger TM. Cytochrome P450 Cyp 2E1 induction during chronic alcohol exposure occurs by a two-step mechanism associated with blood alcohol concentrations in rats. J Pharmacol Exp Ther 1993;264:944-50.

32. Lu Y, Cederbaum AI. CYP2E1 and oxidative liver injury by alcohol. Free Radic Biol Med 2008;44:723-38. doi: 10.1016/ j.freeradbiomed.2007.11.004

33. Tompkins LM, Wallace AD. Mechanisms of Cytochrome P450 Induction. J Biochem Mol Toxicol 2007;21:176-81. doi: $10.1002 /$ jbt. 20180

34. Gonsales JF. CYP2E1. Drug Metab Dispos 2007;35:1-8. doi: $10.1124 / \mathrm{dmd} .106 .012492$

35. Maneesh M, Jayalekshmi H, Dutta S, Chakrabarti A, Vasudevan DM. Role of oxidative stress in ethanol induced germ cell apoptosis - an experimental study in rats. Indian J Clinl Biochem 2005;20:62-7. doi: 10.1007/BF02867402

36. Jiang Y, Kuo CL, Pernecky SJ, Piper WN. The detection of cytochrome P450 2E1 and its catalytic activity in rat testis. Biochem Biophys Res Commun 1998;246:578-83.

37. Forkert P-G., Lash LH, Nadeau V, Tardif R, Simmonds A Metabolism and toxicity of trichloroethylene in epididymis and testis. Toxicol Appl Pharmacol 2002;182:244-54. doi: 10.1006/taap.2002.9421
38. Sikka SC. Relative impact of oxidative stress on male reproductive function. Curr Med Chem 2001;8:851-62. doi: http://dx.doi.org/10.2174/0929867013373039

39. Bootorabi F, Jänis J, Hytönen VP, Valjakka J, Acetaldehydederived modifications on cytosolyc human carbonic anhydrases. J Enzyme Inhib Med Chem 2011;26:862-70. doi: 10.3109/14756366.2011.588227

40. Solís-Calero C, Ortega-Castro J, Muñoz F. Reactivity of a phospholipid monolayer model under periodic boundary conditions: a density functional theory study of the schiff base formation between phosphatidylethanolamine and acetaldehyde. J Phys Chem 2010;114:15879-85. doi: 10.1021/jp1088367

41. Lieber CS. Hepatic, metabolic, and nutritional disorders of alcoholism: from pathogenesis to therapy. Criti Rev Clin Lab Sci 2000;37:551-84.

42. Chamberlain JR, Schwarze U, Wang PR, Hirata RK, Hankenson KD, Pace JM, Underwood RA, Song KM, Sussman M, Byers PH, Russell DW. Gene targeting in stem cells from individuals with osteogenesis imperfecta. Science 2004;303:1198-201. doi: 10.1126/science.1088757

43. He Z, Feng L, Zhang X, Parodi DA, Suarez-Quian C, Dym M. Expression of Colla1, Colla2 and procollagen I in germ cells of immature and adult mouse testis. Reproduction 2005;130:333-41. doi: 10.1530/rep.1.00694

44. Ramachandran GN. Biochemistry of Collagen. New York, London: Plenum Press; 1976.

45. Preedy VR, Sherwood RA, Akpoguma CI, Black D. The urinary excretion of the collagen degradation markers pyridinoline and deoxypyridinoline in an experimental rat model of alcoholic bone disease. Alcohol Alcohol 1991;26:191-8.

46. Patouillard G, Farjanel J, Cordier S, Bayle JJ, Frey J. [Discussion of the interest of estimation of hydroxyprolinuria in chronic alcoholism (author's transl), in French]. Ann Biol Clin (Paris) 1978;36:19-22.

47. Li J, Guo M, Hu B, Liu R, Wang R, Tang C. Does chronic ethanol intake cause chronic pancreatitis?: evidence and mechanism. Pancreas 2008;37:189-95. doi: 10.1097/ MPA.0b013e31816459b7

48. Forsander OA, Pikkarainen JA, Salaspuro MP. A high hepatic concentration of free proline does not induce collagen synthesis in rat liver. Hepatogastroenterology 1983;30:6-8.

49. Seehra GP, Silver FH. Viscoelastic properties of acid- and alkaline-treated human dermis: a correlation between total surface charge and elastic modulus. Skin Res Technol 2006;12:190-8. doi: 10.1111/j.0909-752X.2006.00150.x

50. Pedchenko VK, Chetyrkyn SV, Chuang P, Ham AJ, Saleem MA, Mathieson PW, Hudson BG, Voziyan PA. Mechanism of perturbation of integrin-mediated cell-matrix interactions by reactive carbonyl compounds and its implication for pathogenesis of diabetic nephropathy. Diabetes 2005;54:2952-60. doi: 10.2337/ diabetes.54.10.2952

51. Kornblihtt AR, Gutman A. Molecular biology of the extracellular matrix proteins. Biol Rev 1988;54:465-507. doi: 10.1111/j.1469-185X.1988.tb00668.x

52. van der Rest M, Garrone R. Collagen family of proteins. Faseb J 1991;5:2814-23.

53. Juin A, Billottet C, Moreau V, Destaing O, Albiges-Rizo C, Rosenbaum J, Génot E, Saltel F. Physiological type I collagen 
organization induces the formation of a novel class of linear invadosomes. Mol Biol Cel 2012;23:297-309. doi: 10.1091/ mbc.E11-07-0594

54. Koide T, Takahara Y, Asada S, Nagata K. Xaa-Arg-Gly triplets in the collagen triple helix are dominant binding sites for the molecular chaperone HSP47. J Biol Chem 2002;277:6178-82. doi: 10.1074/jbc.M106497200

55. Novitskiy G, Traore K, Wang L, Trush MA, Mezey E. Effect of ethanol and acetaldehyde on reactive oxygen species production in rat hepatic stellate cells. Alcohol Clin Exp Res 2006;30:1429-35. doi: 10.1111/j.15300277.2006.00171.x

56. Bondarenko LB, Saprykina NA, Kovalenko VM. Lung and spleen contents of free amino acids after pyrazinamide treatment. Acta Toxicologica 2006;14:79-86.

57. Ban H, Shigemitsu K, Yamatsuji T, Haisa M, Nakajo T, Takaoka M, Nobuhisa T, Gunduz M, Tanaka N, Naomoto Y. Arginine and Leucine regulate p70 S6 kinase and 4E-BP1 in intestinal epithelial cells. Int J Mol Med 2004;13:537-43.

58. Inamasu J, Guiot BH, Sachs DC. Ossification of the posterior longitudinal ligament: an update on its biology, epidemiology, and natural history. Neurosurgery 2006;58:1027-39.
59. Norek A, Romanowska-Pietrasiak B, Bal J. [Genetic markers in the pathogenesis of osteopenia and osteoporosis in cystic fibrosis, in Polish]. Med Wieku Rozwoj 2006;10(1 Pt 2):27587.

60. Linos K, Sedivcová M, Cerna K, Sima R, Kazakov DV, Nazeer T, Glazyrin A, Valerian BT, Carlson JA. Extra nuchaltype fibroma associated with elastosis, traumatic neuroma, a rare APC gene missense mutation, and a very rare MUTYH gene polymorphism: a case report and review of the literature*. J Cutan Pathol 2011;38:911-8. doi: 10.1111/ j.1600-0560.2011.01745.x

61. Nieto N, Friedman SL, Cederbaum AI. Cytochrome P450 2E1-derived reactive oxygen species mediate paracrine stimulation of collagen I protein synthesis by hepatic stellate cells. J Biol Chem 2002;277:9853-64.

62. Sapone A, Affatato A, Canistro D, Broccoli M, Trespidi S, Pozzetti L, Biagi GL, Cantelli-Forti G, Paolini M. Induction and suppression of cytochrome P450 isoenzymes and generation of oxygen radicals by procymidone in liver, kidney and lung of CD1 mice. Mutat Res 2003;527:67-80. doi: 10.1016/S0027-5107(03)00055-1 


\title{
Sažetak
}

\section{EKSPRESIJA CYP2E1 U TESTISIMA ŠTAKORA I ALKOHOLOM PROUZROKOVANE PROMJENE INDEKSA SPERMATOGENEZE I KOLAGENA TIPA I}

\begin{abstract}
Ovo istraživanje proučava alkoholom uzrokovane promjene u ekspresiji CYP2E1 mRNA i bjelančevina iz testisa, indeksu spermatogeneze i aminokiselinskom sastavu kolagena tipa I u muških štakora. Albino štakori tipa Wistar podijeljeni su u dvije skupine: I - kontrolna, II - eksperimentalna (kronični alkoholizam, izloženi 150 dana 15-postotnoj vodenoj otopini etanola). Destruktivne promjene u spermatogenetskom epitelu popraćene su smanjenjem broja i pokretljivosti spermija. Ekspresija mRNA gena CYP2E1 i bjelančevina bila je povišena u testisima 3, odnosno 1,4 puta. Također, u kolagenu tipa I ustanovljene su značajno manje količine lizina, glutaminske kiseline, serina, prolina, alanina, valina i fenilalanina, te veće količine ostataka hidroksiprolina, glicina i treonina. Kronična konzumacija etanola uzrokovala je otkazivanje testisa uz izraženu ekspresiju mRNA CYP2E1 i bjelančevina u testisima, te kvantitativne promjene $u$ aminokiselinama kolagena tipa I. Izražene alkoholom prouzrokovane promjene mogle su utjecati na spermatogenetski epitel. Modulacija ekspresije mRNA testikularnog citokroma P450-2E1 i bjelančevina mogla bi promijeniti djelovanje ovoga izozima u ciljnim organima te sudjelovati u mehanizmu gonadotoksičnosti etanola.
\end{abstract}

KLJUČNE RIJEČI: etanol, gonadotoksičnost, kronični alkoholizam, pokretljivost

\section{CORRESPONDING AUTHOR:}

Ganna Mykhailivna Shayakhmetova Institute of Pharmacology \& Toxicology National Academy of Medical Sciences of Ukraine Eugene Pottier 14, Kyiv, 03680, Ukraine E-mail: anna_shayakhmetova@yahoo.com 